Arresting Development 
WORLD COMICS AND GRAPHIC NONFICTION SERIES

FREDERICK LUIS ALDAMA AND CHRISTOPHER GONZALEZ, EDITORS

The World Comics and Graphic Nonfiction series includes monographs and edited volumes that focus on the analysis and interpretation of comic books and graphic nonfiction from around the world. The books published in the series use analytical approaches from literature, art history, cultural studies, communication studies, media studies, and film studies, among other fields, to help define the comic book studies field at a time of great vitality and growth. 
[ CHRISTOPHER PIZZINO ]

\section{Arresting Development}

COMICS AT THE BOUNDARIES OF LITERATURE

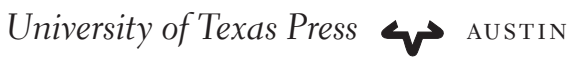


Copyright (C) 2016 by the University of Texas Press

All rights reserved

Printed in the United States of America

First edition, 2016

Requests for permission to reproduce material from this work should be sent to:

Permissions

University of Texas Press

P.O. Box 7819

Austin, TX $78713-7819$

http://utpress.utexas.edu/index.php/rp-form

(2) The paper used in this book meets the minimum requirements of ANSI/NISO Z39.48-1992 (R1997) (Permanence of Paper).

LIBRARY OF CONGRESS CATALOGING-IN-PUBLICATION DATA

Names: Pizzino, Christopher, author.

Title: Arresting development : comics at the boundaries of literature / Christopher Pizzino.

Description: First edition. Austin : University of Texas Press, 2016. Includes bibliographical references and index.

Series: The world comics and graphic nonfiction series

Identifiers: LCCN 2016003031 (print) LCCN 2016005501 (ebook) ISBN 9781477309773 (cloth : alk. paper)

ISBN 9781477310687 (pbk. : alk. paper)

ISBN 9781477309780 (library e-book)

ISBN 9781477309797 (non-library e-book)

Subjects: LCSH: Comic books, strips, etc.-History and criticism.

Classification: LCC PN6714 .P59 2016 (print) LCC PN6714 (ebook) DDC $741.5 / 9-\mathrm{dc} 23$

LC record available at http://LCCN.loc.gov/2016003031

doi: $10.7560 / 309773$ 
For Michael McKeon 
THIS PAGE INTENTIONALLY LEFT BLANK 